\title{
Microclimatic factors and soil characteristics of Arroceros Forest Park in the City of Manila, Philippines
}

\author{
JULIE S. BERAME ${ }^{1, \bullet}$, ERWIN P. ELAZEGUI ${ }^{2}$, MINERVA C. ARENAS ${ }^{3}$, JASON A. OROZCO \\ ${ }^{1}$ Caraga State University. Km 7 NH1, Butuan City, 8600, Philippines. Tel. +63-9199222449, `email: Janveel@yahoo.com \\ ${ }^{2}$ Technological University of the Philippines. Ayala Blvd., Ermita, Manila, 1000 Philippines \\ ${ }^{3}$ Far Eastern University. Nicanor Reyes Street, Sampaloc, Manila, 1015 Philippines \\ ${ }^{2}$ Philippine Normal University. 04 Taft Ave, Ermita, Manila, 1000 Metro Manila, Philippines
}

Manuscript received: 22 August 2021. Revision accepted: 23 October 2021.

\begin{abstract}
Berame JS, Elazegui EP, Arenas MC, Orozco JA. 2021. 2021. Microclimatic factors and soil characteristics of Arroceros Forest Park in the City of Manila, Philippines. Biodiversitas 22: 4956-4962. Microclimatic factors affect many ecosystem functions. However, the challenge of acquiring consistent data has impeded the quantitative assessment of the spatial heterogeneity of soil-climate in Arroceros Forest Park as an artificial urban forest park known as the last lung of the City of Manila. With this unassisted urban forest park, this study aims to determine the microclimatic factors such as light intensity, air temperature, air humidity, wind speed and direction, soil temperature, soil $\mathrm{pH}$, percent organic matter, percent soil moisture and soil texture by using a sieve analysis and textural triangle method to know the status of the forest park. These procedures reveal the soil type available in the park to be clay and loam suitable for growing plants abundantly. Results showed that four microclimate factors viz. air temperature, air humidity, percent organic matter, and soil texture, were highly significant $(p<0.000)$. Additionally, it further revealed that microclimatic factors such as light intensity, wind speed, and soil $\mathrm{pH}$ are essential in an ecosystem. It also found that soil size is a significant parameter for soil characterizations in this kind of study. Finally, the division of soil microsites into different positions based on prevailing light or shade conditions helped assess the significant variations of soil characteristics and conditions within the study area.
\end{abstract}

Keywords: Dynamics, sieve analysis, soil, textural triangle, urban ecosystem, urban forest.

\section{INTRODUCTION}

The Arroceros Forest Park is situated in Ermita, Manila with a total land area of 2.2-hectares. The forest park is famously known as "Manila's last lung," as it is the city's only natural park. During last 2017, the City of Manila was included in the top 10 stressed cities globally due to air pollution and other factors, according to a study conducted by a UK-based firm called Zipjet (Philstar.com 2017). The rapid urbanization in Metro Manila caused the city to have fewer green spaces, which reduced air quality. An additional reason why pollution is present in Metro Manila is massive population growth, infrastructure development, and increased economic activities, which led to the environmental deterioration of Metro Manila (Gorme et al. 2010). The focus is now to provide conservational support to this precious green urban landscape. The relevant study for the determination of the current microclimatic situation of the Arroceros Forest Park has revealed soil moisture and temperature patterns, which affect a wide variety of processes and interactions in the near-surface (Melillo et al. 2002; Seneviratne et al. 2010). Soil moisture plays a vital role in sustaining terrestrial ecosystems, water cycling, erosion, and landscape evolution (Burnett et al. 2008; Penna et al. 2013; Troch et al. 2013; He et al. 2019). Soil moisture significantly controls the atmospheric climate by regulating energy and water balances (Guo and Lin 2018). It also functions as a primary source of moisture for the formation of clouds and precipitation and affects air temperature and boundary-layer stability (Koster et al. 2004). Soil heat provides thermal inertia to the atmospheric climate system (Hauser et al. 2017), mediates landatmosphere gas exchange, determines the coupling between soil moisture and evapotranspiration (ET) (Seneviratne et al. 2010), and influences many biogeochemical and hydropedological processes (Seyfried et al. 2016).

Subsequently, microclimatic factors are reported to significantly impact the different interactions, processes, and disturbances in the entire terrestrial ecosystem (Berame et al. 2021). For example, temperature and $\mathrm{pH}$ level are microclimatic factors that influence the interaction of organisms as temperature varies with climate, topography, location, and other physical characteristics. On the other hand, the soil's $\mathrm{pH}$ level depends on the parent material and geologic time scale but can also react to the vegetation composition. Additional microclimatic factors include light intensity, air temperature, air humidity, wind speed and direction, soil temperature, and soil $\mathrm{pH}$ level. In addition, it can influence the rate of ecosystem processes, disturbance systems, and the biotic community (Chapin III et al. 2016).

The impact of topographic attributes on soil microclimate distribution is dependent on the time of the year. In some cases, vegetation type and coverage can be distinct between contrasting aspects, which influence rainfall infiltration into the soil and the degree of tree shade and associated soil microclimates and erosion (Gutiérrez and Vivoni 2013). Hence, the temporal dynamics of vegetation cover regulate the actual influence of 
topographic factors on soil microclimates (Gutiérrez and Vivoni 2013; Ivanov et al. 2018). In addition, the relationship between the spatial variability of soil moisture and topography varies at different spatial scales.

Consequently, identifying the forest park factors that influence soil climate is key to the development of accurate soil analysis (Hlavinka et al. 2011). With this, studies have signified that topographic relief is dynamic to soil microclimates (Gutiérrez and Vivoni 2013). It is also recognized that topography and land use determine slope insolation and the differentiation in microclimate's influence rainfall infiltration and subsurface flow, resulting in localized soil microclimate management (Liu et al. 2011; Corrao et al. 2017).

On the other hand, soil differs in terms of appearance, forms, functions and uses. Soil types can be clay, silt, and sand (Odum 1994) which varies by particle size and texture. According to size, the soil is composed of particles of sand (2.0-0.05 $\mathrm{mm}$ in diameter), silt (0.05-0.002 mm) and clay (less than $0.002 \mathrm{~mm}$ ) particles (King 2003), while soil texture is divided into three groups such as coarse (sandy soil with 70-100\% sand-sized particles), medium (even distribution of clay and sand particles), and fine (35$40 \%$ clay-sized particles) (Ritchey et al. 2015). Soil texture influences the use of soil in agriculture and the natural ecosystem (Havlicek and Mitchell 2014). It is considered the most vital soil property to influence soil and water relationships (Oli and Subedi 2015). The variations in the soil texture proportions can affect the textural class that determines the features of the soil (Campbell 2014)

Thus, this study aims to utilize the common instruments used to determine the microclimatic factors in the study area and to determine the soil particle size distribution using the sieve method and textural triangle to relate the particle size to the specific surface area in the current status of the Arroceros Forest Park in the City of Manila, Philippines.

\section{MATERIALS AND METHODS}

\section{Study area and sampling}

The Arroceros Forest Park is a protected forest park in the City of Manila located at $14.5942^{\circ} \mathrm{N}, 120.9817^{\circ} \mathrm{E}$ with a total land area of 2.2 ha. This forest is an essential urban greenscape and a hub for active research due to its rich biodiversity supported by an ambient microclimate. The area's climate is humid with annual mean precipitation of $610 \mathrm{~mm}$ and a mean annual air temperature of $7.5^{\circ} \mathrm{C}$. Loam, clay, and silt were predominant as the most prevailing soil particle fractions. The determination of microclimatic factors and soil textures was conducted through the identification of four quadrants.

To cover a varied range in soil characteristics, sampled soils were analyzed using the sieve method and textural triangle method, including ribbon, grittiness, and smoothness tests to determine the soil sample's textural class. It was noted that different quadrats with soil samples were conducted at the site of the study. In January 2020, the study was performed using the four quadrants to determine the microclimatic factors. In soil characterization sampling, the soil texture class identification has used textural triangle and the determination of the particle size has used sieve analysis.

\section{Microclimatic factors}

Light intensity: A light meter was used to collect the light intensity for each quadrant accurately. The light meter was positioned at arm level, pointing the sensor plate towards the light source. The measurement was recorded once the reading had stabilized.

Air temperature, air humidity, wind speed, and wind direction: A pocket weather meter was used to determine the air temperature, air humidity, wind speed, and wind direction.

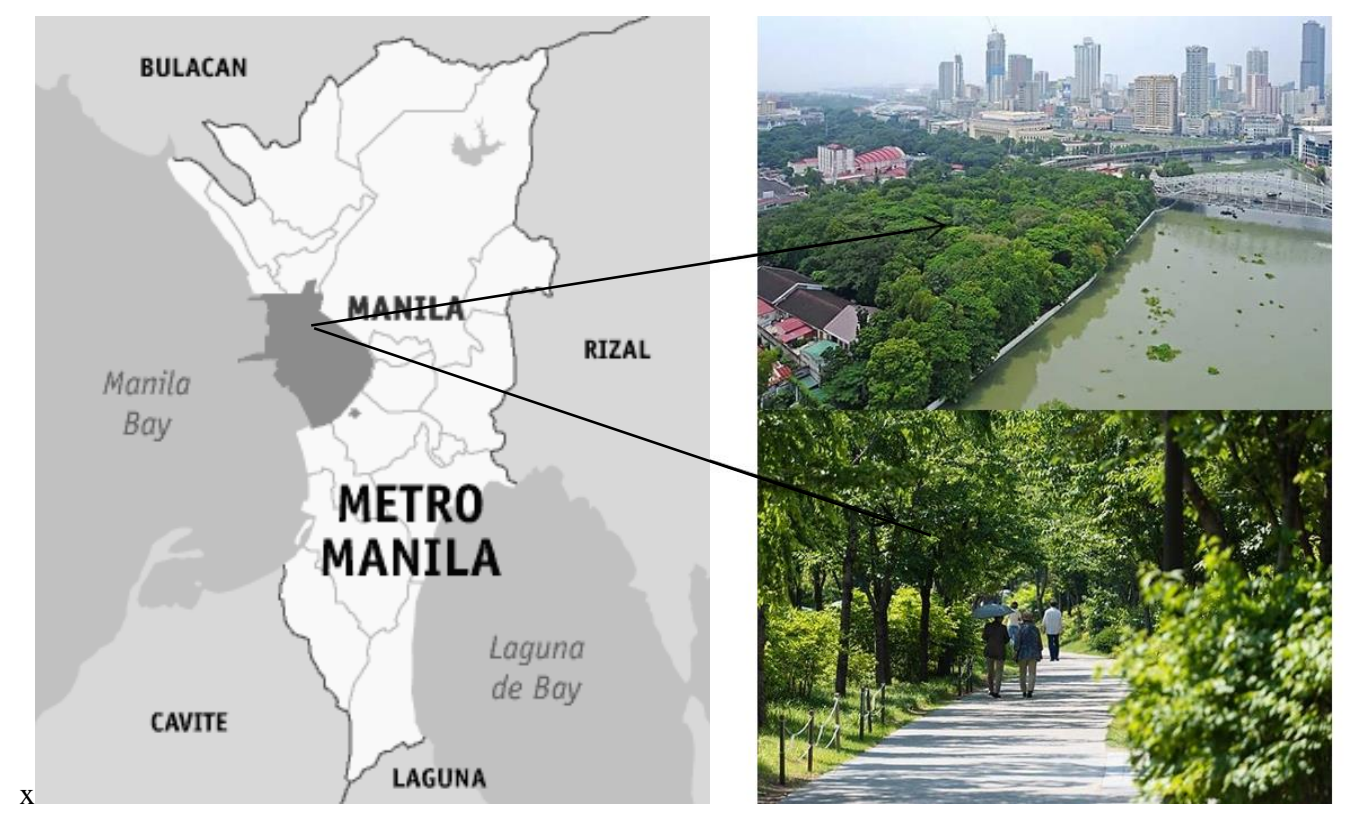

Figure1. Map of Arroceros Forest Park in the heart of the City of Manila, Philippines 
Soil temperature: A soil temperature thermometer was used to determine the temperature of the soil by inserting the metal rod of the soil thermometer in the ground. The soil samples were collected from quadrants 1 to 4 to measure the soil $\mathrm{pH}$. The soil samples were placed on a black plastic bag to avoid light penetration and maintain the dark condition. In the laboratory, the $\mathrm{pH}$ level of the soil samples was determined using CPR/BCG/CPR $\mathrm{pH}$ indicator dyes. The soil samples from four quadrants were placed in separate test tubes. Seven drops of CPR $\mathrm{pH}$ indicator dye were added to each test tube, gently swirled 20 times, repeated twice, and set aside for 5 minutes. Afterward, the $\mathrm{pH}$ of the soil was determined using the corresponding color chart of the $\mathrm{pH}$ indicator.

Percent soil organic matter: $25 \mathrm{~g}$ dry weight soil sample from each quadrant was placed in a separate crucible with cover. The soil sample in crucibles was a furnace for 168 hours. The percent soil organic matter was obtained by subtracting initial dry weight from ignited weight and multiplying it to 100 .

Percent soil moisture: $25 \mathrm{~g}$ fresh weight soil sample was placed in a white paper bag. The soil sample was oven dried for 56 hours at $9000 \mathrm{C}$ and measured to determine the dry weight. The final weight was obtained to determine the percent moisture content of the soil by getting the difference between the fresh and dry weight and multiplied to 100 .

\section{Particle size analysis}

Textural triangle was used to determine the soil textural class by identifying the percentages of silt, sand, and clay (Lekaj et al. 2016).

Sieve analysis was used with soil samples weighing 100 g. At first, soil samples were oven-dried to pass through sieve \#35, sieve \#40, and sieve \#45. Next, the sieve was agitated in the sample rolls on irregular motion over the sieve. Finally, the material retained on the sieve was rubbed using mortar and pestle. The collected materials from each sieve were placed on pre-weigh paper boxes and weighed. The percentage of soil retained on each sieve was calculated based on the total mass of the sample to determine the soil textural class.

\section{Statistical analysis}

The study performed statistical analysis such as mean, standard deviation, and f-test to determine differences after testing data to meet conditions of normality and homogeneity. Probability values of $p<0.05$ were considered significant. Data analysis was conducted through PAST statistical data analysis software.

\section{RESULTS AND DISCUSSION}

\section{Microclimatic factors}

The results of a study conducted on some of the microclimatic variables are summarized in Table 1. From the study, the wind speed and wind direction and soil $\mathrm{pH}$ were constant variables that were not significant.

As presented in Table 1, there was no significant difference in the light intensity in the four quadrants identified in Arroceros Forest Park with a p-value $=0.066$. This suggests that the light intensity in the area is almost the same because of the tall trees present and the wind speed. During the data collection, the wind speed was constant due to the surrounding of the area by trees. The other continuous variable, such as soil $\mathrm{pH}$, was not significant, possibly due to rain, temperature, and dissolved minerals in the area.

In addition, the air temperature was significant ( $\mathrm{p}$-value $=0.00)$, possibly due to the location of the forest park, which is situated beside the Pasig River, Quiapo Bridge, LRT 1 Station, nearby condominiums, and establishments. Furthermore, air humidity was significant with a p-value $=$ 0.00 due to the plant diversity in the forest park (trees, shrubs, herbs, grass), cars passing nearby the park, and air temperature. More so, soil temperature $(\mathrm{p}$-value $=0.00)$ is possibly affected by plant vegetation, soil moisture, and slope of forest park. Similarly, the percent organic matter was significant ( $p$-value $=0.00$ ). This is possibly an expected fact that the forest park receives the same amount of rain, soil moisture, and climate. Lastly, soil moisture was also significant with a p-value $=0.00$ because it was directly affected by the topography, water supply, and soil humidity.

\section{Soil characteristics}

As presented in Table 2, the composition of sand, silt, and clay for the textural class is more profound from one texture to another. As assumed in the study, soil texture may contribute to each microbial group (Lauber et al. 2008). It further reported that sand was responsible for general bacteria variability according to Johnson et al. (2003), soil type and physical properties could influence microbial community composition and soil texture had a more substantial effect than plant species.

Table 1. Summary table of microclimatic factors of Arroceros Forest Park, City of Manila, Philippines

\begin{tabular}{lccccl}
\hline \multicolumn{1}{c}{ Factors } & Mean & SD & F-Test & p-value & Remarks \\
\hline Light intensity & 20.468 & 0.048 & 3.117 & 0.066 & Not Significant \\
Air temperature & 31.433 & 0.048 & 35.933 & 0.000 & Significant \\
Air humidity & 68.525 & 0.068 & 2426.500 & 0.000 & Significant \\
Wind speed and direction & 20.000 & 0.000 & \multicolumn{2}{c}{ Constant variable } & Not Significant \\
Soil temperature & 28.140 & 0.191 & 36.461 & 0.000 & Significant \\
Soil pH & 5.000 & 0.000 & \multicolumn{2}{c}{ Constant variable } & Not Significant \\
Percent organic matter & 5.690 & 0.046 & 76.634 & 0.000 & Significant \\
Soil moisture & 6.655 & 0.022 & 3936.684 & 0.000 & Significant \\
\hline
\end{tabular}


Using the textural triangle, Table 3 contains the textural classes of the soil samples. For example, the proportion of sand, silt, and clay from soil sample $\mathrm{S} 1$ intersected at the area of clay loam, similarly, sample S2 crossed at the area of loam; soil sample S3 intersected at the area of sandy loam; soil sample S4 intersected at the area of silt loam; soil sample S5 intersected at the area of clay; soil sample S6 intersected at the area of sandy clay, and soil sample S7 crossed at the area loam (King 2003; Hewitt 2015).

Meanwhile, Table 4 displays the textural quality of soil samples that were determined using the feel method. Based on the findings, the three soil samples $\mathrm{A}$ to $\mathrm{C}$ formed a ball, produced ribbons longer than $5 \mathrm{~cm}$, were predominated by wet texture. Therefore, considering these characteristics of these three soil samples were classified as clay loam.

\section{Soil-landscape attributes indexes}

Environmental factors such as soil-landscape, parent material, climate, and vegetation cover substantially influence the variability of sub-factors like moisture availability, temperature (soil and air), and nutrient availability that regulate the forest ecosystem's variability (Tamai 2010; He et al. 2016). Various studies emphasized that soil-landscape had good potential to explain a large part of the variability in soil properties within a given environment (Ayoubi et al. 2012; Zeraatpisheh et al. 2019). Rodrigo-Comino et al. (2016) showed that soil erosion could affect the distribution of the surface soil components.

Table 2. Particle size conversion table

\begin{tabular}{llc}
\hline \multicolumn{2}{c}{ Sieve designation } & Nominal sieve opening \\
\hline Standard & Mesh & Inches \\
$0.500 \mathrm{~mm}$ & No. 35 & 0.0197 \\
$0.420 \mathrm{~mm}$ & No. 40 & 0.0165 \\
$0.354 \mathrm{~mm}$ & No. 45 & 0.0139 \\
\hline
\end{tabular}

Table 3. Summary table of the $\%$ composition of sand, silt, and clay for textural class

\begin{tabular}{ccccl}
\hline $\begin{array}{c}\text { Soil } \\
\text { sample }\end{array}$ & \% Sand & \% Silt & \% Clay & Textural class \\
\hline S1 & 33 & 33 & 34 & Clay loam \\
S2 & 50 & 30 & 20 & Loam \\
S3 & 80 & 5 & 15 & Sandy loam \\
S4 & 25 & 60 & 15 & Silt loam \\
S5 & 30 & 20 & 50 & Clay \\
S6 & 60 & 10 & 30 & Sandy clay loam \\
S7 & 40 & 40 & 20 & Loam \\
\hline
\end{tabular}

Table 4. Unknown soil samples describing the textural class using feel method analysis

\begin{tabular}{cccccc}
\hline $\begin{array}{c}\text { Soil } \\
\text { sample }\end{array}$ & $\begin{array}{c}\text { Does it } \\
\text { make a } \\
\text { ball? }\end{array}$ & $\begin{array}{c}\text { Does it } \\
\text { make a } \\
\text { Ribbon? }\end{array}$ & $\begin{array}{c}\text { Ribbon } \\
\text { length }\end{array}$ & $\begin{array}{c}\text { Pre- } \\
\text { dominate } \\
\text { wet feel }\end{array}$ & $\begin{array}{c}\text { Textural } \\
\text { class }\end{array}$ \\
\hline $\mathrm{A}$ & Yes & Yes & $>5 \mathrm{~cm}$ & Yes & Clay loam \\
$\mathrm{B}$ & Yes & Yes & $>5 \mathrm{~cm}$ & Yes & Clay loam \\
$\mathrm{C}$ & Yes & Yes & $>5 \mathrm{~cm}$ & Yes & Clay loam \\
\hline
\end{tabular}

Although the interpretations of ecosystem interactions are complex, some novel insights between soil and topographic attributes have been found. The feel method analysis and sensitivity results showed that soil parameters were influenced by soil-landscape and microclimatic conditions (Bramer et al. 2018; Naiman and Likens, 2018).

Succeedingly, quantitative landscape attributes in the area were supposedly affected through the surface and elevation of the forest had a significant contribution to soil variability. It has been understood that elevation slope, height, and aspect attributes have considerable effects on soil temperature, water content, and soil redistribution rate (Liu et al. 2011). Some studies have indicated those landscape attributes, including gradients of elevation, latitudinal variation, and soil moisture index, play an essential role in the soil variability (Coblentz and Riitters 2004). The mentioned influences on soil-landscape and received sunlight intensity (short wave and long wave) and the resultant soil temperature are major causes of spatial variation of soil surface energy, water balance, which ultimately affect forest ground ecosystem (Florinsky et al. 2002; Bohner and Antonic 2009). Land elevation, forest shading, mid-slope, and landscape are closely related to solar radiation and soil temperature, affecting organic matter decomposition (He et al. 2016).

Therefore, a substantial variation in soil within the study area might be ascribed to variation in topographic attributes that regulate soil availability and redistribution. As trees covered in the study are considerable, it could control the amount of sunlight reaching the forest ground and the soil surface temperature. Moreover, in the forest ecosystems, differences in litter leaf quality of tree species (Bardgett and van der Putten 2014) and root exudates (Eisenhauer and Reich 2012) could lead to variability in soil. Vegetation indexes can indirectly and directly affect soil properties (Bishop and Minasny 2005).

\section{Effects of soil size variability's and characteristics}

Division of soil microsites into different positions based on the prevailing light or shade conditions helped assess the significant variations of soil conditions

In addition, results support the comments on the importance of soil characterizations and soil position effects on the variations of the forest conditions in different soil sizes (Latif and Blackburn 2010; Čater et al. 2014; Vilhar et al. 2015). Higher penetration levels of solar radiation in significant gaps were responsible for the lowest soil moisture content measured at the center. The center being the most exposed position to light (solar radiation), the anticipation of fast evaporation conditions leading to lower moisture content was expected.

Interestingly, the variability of soil temperature was explainable within the study area and size factors. This result confirms that in the different sizes, soil temperature across other areas of the forest differs. The coverage of the relatively dense herbaceous layer at the forest floor blocked soil surfaces from the direct heating-up effect of the incoming solar radiation. This, therefore, led to the observation of low soil temperature across the forest area. Contrarily, quadrant four had low coverage of herbaceous 
layer enabled heating-up of the soil surfaces by penetrative solar radiation, resulting in high soil temperature across the forest locations. Further, the heavy shading conditions have caused comparable soil temperature readings across studied forest areas. In general, findings suggest that soil temperature variations under different forest positions and locations of various sizes are closely connected to the complex interaction of shading and insulating effects of undergrowth vegetation. Nonetheless, this recommendation is subjective to further future studies (Ritter et al. 2005).

\section{Soil and microorganisms influence in the forest ecosystem}

It was noticed in the study that organic carbon, $\mathrm{pH}$, and soil particle distribution were the most important factors among the soil properties. Studies have demonstrated that soil properties could regulate the activity in the floor ecosystem (Wang et al. 2017). Findings showed that organic carbon had a strong direct effect and showed a strong indirect effect on soil. Various studies have confirmed direct and indirect interaction between organic carbon and microorganisms an essential part of the carbon and nitrogen cycle in the ecosystems (Aislabie and Deslippe 2013). Also, through their associated enzymes, they regulate the amount of carbon and nitrogen in soil (Cusack et al. 2011). In addition, soil microorganisms play an essential role in soil structure through binding soil particles and organic matter (Six et al. 2000; McMahon et al. 2005; Williams et al. 2006).

Basically, the intracellular $\mathrm{pH}$ of nearly all microorganisms in an ecosystem is usually within $1 \mathrm{pH}$ unit from neutral, thus soil $\mathrm{pH}$ may be an unbiased driver of microbe diversity (Madigan et al. 2006). More so, it has been shown that soil $\mathrm{pH}$ is one of the main factors in soil bacteria distribution and can be used as an only predictor variable in large (Fierer and Jackson 2006). Further, Lauber et al. (2008) confirmed that soil bacteria were related to soil $\mathrm{pH}$, which was the top predictor of soil bacteria across the landscape or soil surface. On the contrary, Wang et al. (2013) has stated that $\mathrm{pH}$ has no significant direct effect on soil microorganisms and Brocket et al. (2012) have shown that soil $\mathrm{pH}$ was not the explanatory variable for microbial community function.

Soil microorganisms are primarily attached to soil particles. In this regard, findings showed that different soil particle fractions had varying effects on other microbial groups. Silt and sand were directly correlated. However, the indirect analysis was affected by particle size fractions. Various studies (Bach et al. 2010) informed that there is higher microbial biomass and more diversity in silt and clay fractions. One possible explanation for these results is that finer size particles provide small pore sizes of soil particles. In addition, silt and clay particles have more water holding capability and impact water and nutrient availability (Bach et al. 2010).

This study revealed that microclimatic factors such as light intensity, wind speed, and soil $\mathrm{pH}$ are significant factors in an ecosystem. Wind speed and soil $\mathrm{pH}$ for all the quadrants were at a constant value. Air temperature, air humidity, soil temperature, percent organic matter, and soil moisture were found highly significant among the four quadrants, as shown in the study. The value of these microclimatic factors from four quadrants differed significantly. On the other hand, the use of a textural triangle was helpful to determine the point area where the percentage of sand, silt, and clay intersected. Results showed that the mass of retained soil per sieve level and its percentages were essential to determine which soil particles could be clay, silt, and sand in sieve analysis. This was done by comparing the weight per level to the standard sizes of the particle. The soil size was found to be a significant parameter for soil characterizations and further investigation in this regard is advised. Finally, soil sensitivity analysis indicated that soil-landscape attributes and vegetation indexes were influential parameters and could indicate soil microorganisms for soil quality assessment and analysis in forest soils.

\section{ACKNOWLEDGEMENTS}

The authors are grateful to acknowledge Dr. Emelina H. Mandia of Biology Department, De La Salle University, Taft, Manila, Prof. Erwin P. Elazegui of Technological University of the Philippines, Manila and Prof. Minerva C. Arenas of Far Eastern University, Manila for providing technical assistance in the conduct of the study. Furthermore, the authors declare that they have no known competing financial interests that could have appeared to influence the work reported in this paper.

\section{REFERENCES}

Aislabie J, Deslippe JR. 2013. Soil microbes and their contribution to soil services. In: Dymond JR (eds). Ecosystem Services in New ZealandConditions and Trends. Manaaki Whenua Press, Lincoln, New Zealand.

Ayoubi S, Mokhtari P, Reza M, Honarjoo N. 2012. Soil aggregation and organic carbon as affected by topography and land use change in western Iran. Soil Tillage Res 121: 18-26. DOI: 10.1016/j.still.2012.01.011

Bach EM, Baer SG, Meyer CK, Six J. 2010. Soil texture affects soil microbial and structural recovery during grassland restoration. Soil Biol Biochem 42: 2182-2191. DOI: 10.1016/j.soilbio.2010.08.014

Bardgett RD, van der Putten WH. 2014. Belowground biodiversity and ecosystem functioning. Nature 515: 505-511. DOI: $10.1038 /$ nature 13855

Berame JS, Bulay ML, Mercado RL. 2021. Sustaining angiosperms' diversity of Bood Promontory and Eco-Park, Butuan City, Philippines: Step towards a community based-protection management program. Biodiversitas 22: 2519-2527. DOI: 10.13057/biodiv/d220662

Bishop T, Minasny B. 2005. Digital soil-terrain modeling: The predictive potential and uncertainty. In: Environmental Soil-Landscape Modeling, pp. 185-213. DOI: 10.1201/9781420028188.sec3

Bohner J, Antonic O. 2009. Land-surface parameters specific to topoclimatology. In: Hengl T, Reuter HI (eds). Geomorphometry Concepts, Software, Applications. Elsevier, Amsterdam. DOI: 1016/S0166-2481(08)00008-1.

Bramer I, Anderson BJ, Bennie J, Bladon AJ, De Frenne P, Hemming D, Hill RA, Kearney MR, Körner C, Korstjens AH, Lenoir J, Maclean IMD, Marsh CD, Morecroft MD, Ohlemüller R, Slater HD, Suggitt AJ, Zellweger F, Gillingham PK. 2018. Advances in monitoring and modelling climate at ecologically relevant scales. In: Bohan DA, Dumbrell AJ, Woodward G, Jackson M (eds). Advances in Ecological Research: Vol. 58. Next Generation Biomonitoring: Part 1. Elsevier, San Diego, CA. DOI: 10.1016/bs.aecr.2017.12.005 
Brockett BFT, Prescott CE, Grayston SJ. 2012. Soil moisture is the major factor influencing microbial community structure and enzyme activities across seven biogeoclimatic zones in western Canada. Soil Biol Biochem 44: 9-20. DOI: 10.1016/j.soilbio.2011.09.003

Burnett BN, Meyer GA, McFadden LD. 2008. Aspect-related microclimatic influences on slope forms and processes, northeastern Arizona. J Geophys Res-Earth 113 (F3): 1-18. 882. DOI: 10.1029/2007JF000789

Campbell B. 2014. Biology. McGrawHill Company, United States of America.

Chapin III F, Vicca S, Luyssaert S, Peñuelas J, Campioli M, Ciais P, Heinemeyer A. 2016. Fertile forests produce biomass more efficiently. Ecol Lett 5 (6): 520-526. DOI: 10.1111/j.14610248.2012.01775.x

Čater M, Diaci J, Roženbergar D. 2014. Gap size and position influence variable response of Fagus sylvatica L. and Abies alba Mill. For Ecol Manag 325: 128-135. DOI: 10.1016/j.foreco.2014.04.001

Coblentz DD, Riitters KH. 2004. Topographic controls on the regional scale biodiversity of the south-western USA. J Biogeogr 31: 11251138. DOI: 10.1111/j.1365-2699.2004.00981.x

Corrao MV, Link TE, Heinse R, Eitel JUH. 2017. Modeling of terracettehillslope soil moisture as a function of aspect, slope and vegetation in a semi-arid environment. Earth Surf Proc Land 42 (10): 1560-1572. 89. DOI: $10.1002 /$ esp.4114

Cusack DF, Silver WL, Torn MS, Burton SD, Firestone MK. 2011 Changes in microbial community characteristics and soil organic matter with nitrogen additions in two tropical forests. Ecology 92 (3): 621-632. DOI: 10.1890/10-0459.1

Eisenhauer N, Reich PB. 2012. Above and below-ground plant inputs both fuel soil food webs. Soil Biol Biochem 45: 156-160. DOI 10.1016/j.soilbio.2011.10.019

Fierer N, Jackson R. 2006. The diversity and biogeography of soil bacterial communities. Proc Natl Acad Sci USA 103: 626-631. DOI: 10.1073/0507535103.

Florinsky I, Eilers R, Manning G, Fuller L. 2002. Prediction of soil properties by digital terrain modelling. Environ Model Softw 17: 295 311. DOI: 10.1016/S1364-8152(01)00067-6.

Guo L, Lin H. 2018. Addressing two bottlenecks to advance the understanding of preferential flow in soils. Adv Agron 147: 61-117. 936. DOI: $10.1016 /$ bs.agron.2017.10.002

Gorme JB, Maniquiz MC, Sung P, Kim LH. 2010. The water quality of the Pasig River in the City of Manila, Philippines: Current status, management and future recovery. Environ Eng Res 15 (3): 73-179. DOI: 10.4491/eer.2010.15.3.173

Gutiérrez-Jurado HA, Vivoni ER. 2013. Ecogeomorphic expressions of an aspect controlled semiarid basin: II. Topographic and vegetation controls on solar irradiance. Ecohydrology 6 (1): 24-37. 942. DOI: 10.1002/eco. 1263

Hauser M, Orth R, Seneviratne SI. 2017. Investigating soil moisture climate interactions with prescribed soil moisture experiments: An assessment with the Community Earth System Model (version 1.2). Geosci Model Dev 10 (4): 1665-1677. DOI: 10.5194/gmd-10-16652017

Havlicek E, Mitchell EA. 2014. Soils supporting biodiversity. In: Dighton J, Krumins JA (eds). Interactions in Soil: Promoting Plant Growth 1 27-58. DOI: 10.1007/978-94-017-8890-8

Hlavinka P, Trnka M, Balek J, Semerádová D, Hayes M, Svoboda M, Eitzinger J, Možný M, Fischer M, Hunt E, Žalud Z. 2011 Development and evaluation of the SoilClim model for water balance and soil climate estimates. Agric Water Manag 98 (8): 1249-1261. DOI: 10.1016/j.agwat.2011.03.011.

He X, Hou E, Liu Y, Wen D. 2016. Altitudinal patterns and controls of plant and soil nutrient concentrations and stoichiometry in subtropical China. Sci Rep 6: 24261. DOI: 10.1038/srep24261

He B, Wang SR, Guo LL, Wu XC. 2019. Aridity change and its correlation with greening over drylands. Agric For Meteorol 278: 1-9. DOI: $10.1016 /$ j.agrformet.2019.107663

Hewitt S. 2015. Conceptual Integrated Science. Pearson Education, United States of America

Ivanov V, Brum M, Vadeboncoeur M, Asbjornsen H. 2018. Hydrological niche segregation defines forest structure and drought tolerance strategies in a seasonal Amazon forest. Ecology 107: 318-333. DOI: 10.1111/1365-2745.13022

Johnson G, Kanowski J, Proctor H, Reis T. 2003. Development of forest structure on cleared rainforest land in eastern Australia under different styles of reforestation. For Ecol Manag 183 (1-3): 265-280. DOI: 10.1016/S0378-1127(03)00109-9

King L. 2003. Earth science IEEE transactions on geoscience and remote sensing, United States of America

Koster RD, Dirmeyer PA, Guo Z, Bonan G, Chan E, Cox P, Gordon CT, Kanae S, Kowalczyk E, Lawrence D, Liu P, Lu CH, Malyshev S, McAvaney B, Mitchell K, Mocko D, Oki T, Oleson K, Pitman A, Sud YC, Taylor CM, Verseghy D, Vasic R, Xue Y Yamada T. 2004. Regions of strong coupling between soil moisture and precipitation. Science 305 (5687): 1138-1140. DOI: 10.1126/science.1100217

Latif ZA, Blackburn GA. 2010. The effects of gap size on some microclimate variables during late summer and autumn in a temperate broadleaved deciduous forest. Int J Biometeorol 54: 119129. DOI: $10.1007 / \mathrm{s} 00484-009-0260-1$

Lauber C, Strickland M, Bradford M, Fiererac N. 2008. The influence of soil properties on the structure of bacterial and fungal communities across land-use types. Soil Biol Biochem 40 (9): 2407-2415. DOI: 10.1016/j.soilbio.2008.05.021

Lekaj O, Gjongecaj B, Mziu P, Lekaj P. 2016. Replacing textural triangle with cumulative particle-size distribution curves. J Balk Ecol 19 (4): 361-366

Liu X, Luo T, Liu X. 2011. Spatiotemporal variability of soil temperature and moisture across two contrasting timberline ecotones in the Sergyemla Mountains, Southeast Tibet. Arct Antarct Alp Res 43: 229-238. DOI: 10.1657/1938-4246-43.2.229

Madigan MT, Martinko JM, Brock TD. 2006. Brock Biology of Microorganisms. Pearson Prentice Hall, Upper Saddle River, NJ, USA.

McMahon SK, Williams MA, Bottomley PJ, Myrold DD. 2005. Dynamics of microbial communities during decomposition of carbon-13 labeled ryegrass fractions in soil. Soil Sci Soc Am J 69: 1238-1247.DOI: 10.2136/sssaj2004.0289

Melillo JM Steudler PA, Aber JD, Newkirk K, Lux H, Bowles FP, Catricala C, Magill A, Ahrens T, Morrisseau S. 2002. Soil warming and carbon-cycle feedbacks to the climate system. Science 298 (5601): 2173-2176. DOI: 10.1126/science.1074153

Odum K 1994. Principles of Ecology, $3^{\text {rd }}$ Edition. McGrawHill Company, United States of America.

Oli BN, Subedi MR. 2015. Effects of management activities on vegetation diversity, dispersion pattern and stand structure of communitymanaged forest in Nepal. Intl J Biodivers Sci Ecosyst Serv Manag 11 (2): 96-105. DOI: 10.1080/21513732.2014.984334

Penna D, Brocca L, Borga M, Dalla FG. 2013. Soil moisture temporal stability at different depths on two alpine hillslopes during wet and dry periods. J Hydrol 477: 55-71. DOI: 10.1016/j.jhydrol.2012.10.052

Philstar.com. 2017. Manila named $10^{\text {th }}$ most stressful city in the world. https:/www.philstar.com/headlines/2017/09/14/1739115/manilanamed-10th-most-stressful-city-world.

Ritchey EL, McGrath JM, Gehring D. 2015. Determining Soil Texture by Feel. Agriculture and Natural Resources Publications 139. Cooperative Extension Service, College of Agriculture, Food and Environment, University of Kentucky Lexington, KY, https://uknowledge.uky.edu/anr_reports/139

Ritter E, Dalsgaard L, Einhorn KS. 2005. Light, temperature and soil moisture regimes following gap formation in a semi-natural beechdominated forest in Denmark. For Ecol Manag 206 (1-3): 15-33. DOI: 10.1016/j.foreco.2004.08.011

Rodrigo-Comino J, Ruiz-sinoga JD, Sinoga JD, González JM, Guerramerchán A, Seeger M, Ries JB. 2016. High variability of soil erosion and hydrological processes in Mediterranean hillslope vineyards. Catena 145: 274-284. DOI: 10.1016/j.catena.2016.06.012

Seneviratne SI, Corti T, Davin EL, Hirschi M, Jaeger EB, Lehner I, Orlowsky B, Teuling AJ. 2010. Investigating soil moisture-climate interactions in a changing climate: A review. Earth-Sci Rev 99 (3-4): 125-161. 1039. DOI: 10.1016/j.earscirev.2010.02.004

Seyfried M, Link T, Marks D, Murdock M. 2016. Soil temperature variability in complex terrain measured using fiber-optic distributed temperature sensing. Vadose Zone J 15 (6): 1-18. DOI: 10.2136/vzj2015.09.0128

Six J, Elliot ET, Paustian K. 2000. Soil micro aggregate turnover and micro aggregate formation: A mechanism for $\mathrm{C}$ organic under notillage agriculture. Soil Biol Biochem 32: 2099-2103. DOI: 10.1016/S0038-0717(00)00179-6

Tamai K. 2010. Effects of environmental factors and soil properties on topographic variations of soil respiration. Biogeosciences 7: 11331142. DOI: 10.5194/bgd-6-10935-2009 
Troch PA, Carrillo G, Sivapalan M, Wagener T, Sawicz K. 2013. Climatevegetation-soil interactions and long-term hydrologic partitioning: signatures of catchment co-evolution. Hydrol Earth Syst Sci 17 (6): 2209-2217 DOI: 10.5194/hess-17-2209-2013

Vilhar U, Roženbergar D, Simončič P, Diaci J. 2015. Variation in irradiance, soil features and regeneration patterns in experimental forest canopy gaps. Ann For Sci 72: 253-266 DOI: 10.1007/s13595014-0424-y

Wang R, Zhang H, Sun L, Qi G, Chen S, Zhao X. 2017. Microbial community composition is related to soil biological and chemical properties and bacterial wilt outbreak. Sci Rep 7 (1): 343. DOI: 10.1038/s41598-017-00472-6.

Williams MA, Myrold DD, Bottomley PJ. 2006. Carbon flow from 13Clabeled straw and root residues into the phospholipid fatty acids of a soil microbial community under field conditions. Soil Biol Biochem 38 759-768. DOI: 10.1016/j.soilbio.2005.07.001

Zeraatpisheh M, Ayoubi S, Sulieman M, Rodrigo-Comino J. 2019. Determining the spatial distribution of soil properties using the environmental covariates and multivariate statistical analysis: A case study in semi-arid regions of Iran. J Arid Land 11: 551-566. DOI: 10.1007/s40333-019-0059-9 